\title{
Quasi-Markets and Social Policy
}


Quasi-Markets and Social Policy

Edited by

Julian Le Grand

and

Will Bartlett 


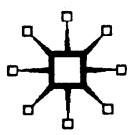

Selection, editorial matter, Chapters 1, 2 and 9 (C) Julian Le Grand and Will Bartlett 1993

Individual chapters (C) Will Bartlett, Will Bartlett and Lyn Harrison, Glen Bramley, Lesley Hoyes and Robin Means, Carol Propper 1993

All rights reserved. No reproduction, copy or transmission of this publication may be made without written permission.

No paragraph of this publication may be reproduced, copied or transmitted save with written permission or in accordance with the provisions of the Copyright, Designs and Patents Act 1988, or under the terms of any licence permitting limited copying issued by the Copyright Licensing Agency, 90 Tottenham Court Road, London W1P 9HE.

Any person who does any unauthorised act in relation to this publication may be liable to criminal prosecution and civil claims for damages.

First published 1993 by

THE MACMILLAN PRESS LTD

Houndmills, Basingstoke, Hampshire RG21 2XS

and London

Companies and representatives

throughout the world

ISBN 978-0-333-56519-3 ISBN 978-1-349-22873-7 (eBook)

DOI 10.1007/978-1-349-22873-7

A catalogue record for this book is available from the British Library.

Copy-edited and typeset by Povey-Edmondson

Okehampton and Rochdale, England 


\section{Contents}

Acknowledgements vii

Notes on the Contributors viii

1 Introduction 1

2 The Theory of QuasiMarkets 13

Will Bartlett and Julian Le Grand

3 Quasi-Markets, Contracts and Quality in Health and Social Care: The US Experience 35 Carol Propper

4 Quasi-Markets and the National Health Service Reforms 68 Will Bartlett and Lyn Harrison

5 Quasi-Markets and the Reform of Community Care 93 Lesley Hoyes and Robin Means

6 Quasi-Markets and Educational Reforms 125

Will Bartlett 
vi Contents

7 Quasi-Markets and Social Housing 154

Glen Bramley

8 Quasi-Markets and

Regulation 183

Carol Propper

Q Quasi-Markets and Social Policy: The Way Forward? 202

Julian Le Grand and Will Bartlett

References 221

Index 230 


\section{Acknowledgements}

This book is an outcome of the Quasi-Markets Programme set up by the School for Advanced Urban Studies in 1989. The writing of the book and most of the research reported in it was funded by the Economic and Social Research Council under Grant No. W-102-251016, as part of the Functioning of Markets Initiative. Other funders who have contributed to the Quasi-Markets Programme include the Joseph Rowntree Foundation and the King Edward's Hospital Fund for London. We are grateful to all these organisations for their support.

Although each chapter of the book is individually attributed, all have been discussed and commented on by members of the QuasiMarket Programme. The book is thus in large part the product of a collective enterprise, although the contributors vary in their optimism about the ability of quasi-markets to improve the delivery of welfare services. We are grateful to Gervas Huxley and Marilyn Taylor for their contributions to those discussions. There have also been many fruitful debates of the relevant issues with Howard Glennerster and other members of the Welfare State Programme at the LSE. John Cable, Research Co-ordinator of the ESRC's Functioning of Markets Initiative, organised useful workshops as part of the Initiative; he has also contributed directly to the project in several other ways. Much of the material has been presented in other seminars, workshops and lectures throughout Britain and elsewhere; although too numerous to list, we are grateful to the participants of those occasions for stimulating questions and comments.

Lorraine Cantle has helped organise the production of the manuscript with her usual efficiency and good humour. Other members of the SAUS support staff have helped in a number of small but significant ways. And our families have bravely put up with the dislocation to domestic life that inevitably seems to accompany this kind of project. To them all, our deepest thanks.

Julian Le Grand Will Bartlett 


\section{Notes on the Contributors}

Julian Le Grand is the Richard Titmuss Professor of Health Policy at the London School of Economics and Professorial Fellow, King's Fund Institute. Previously he was Professor of Public Policy and Director of the School for Advanced Urban Studies, University of Bristol. $\mathrm{He}$ is a leading authority on the economics of the welfare state. His recent publications include The Economics of Social Problems (with Carol Propper and Ray Robinson) and Equity and Choice.

Will Bartlett is a Research Fellow at the School for Advanced Urban Studies, University of Bristol, researching into the role of quasi-markets in the provision of welfare services. He has previously worked at the Universities of Bath and Southampton and at the European University Institute in Florence.

Glen Bramley is a Senior Lecturer in the School for Advanced Urban Studies, University of Bristol, specialising in housing, local government finance and the economic analysis of public policy. $\mathrm{He}$ has written extensively on housing finance, needs affordability and supply, on equalisation grants to local government, and on more general policy analysis issues.

Lyn Harrison is a Lecturer in Health Policy at the School for Advanced Urban Studies, University of Bristol. She is working on a range of research and evaluation projects concerned with the implementation of quasi-market reforms in health and social care.

Lesley Hoyes is a Research Fellow at the School for Advanced Urban Studies, University of Bristol. She has undertaken considerable research and consultancy work around her central interest in the development and implementation of community care policies. She is currently joint director (with Robin Means) of a major 
research project studying the impact of community care reforms on users and carers.

Robin Means is a Lecturer in Social Policy at the School for Advanced Urban Studies, University of Bristol, where he has worked on housing and social care issues. $\mathrm{He}$ is currently joint director (with Lesley Hoyes) of a research project studying the impact of community care reforms upon users and carers.

Carol Propper is a Lecturer in the Department of Economics and the School for Advanced Urban Studies, University of Bristol. She specialises in the economic analysis of health care markets. She publishes regularly in economic journals and has recently coauthored The Economics of Social Problems (with Julian Le Grand and Ray Robinson). 